\title{
Development of Films, Based on Oxidized Ipomea Batatas Starch, with Protein Encapsulation
}

\section{Desarrollo de Películas, Basadas en Almidón Oxidado de Ipomea Batatas, con Encapsulación de Proteínas}

\author{
J. F. Alvarez-Barreto, D. Viteri-Narvaez, J. S. Proano, A. Caicedo, M. Grunauer, L. Eguiguren, M. Vargas \\ Universidad San Francisco de Quito, USFQ
}

\begin{abstract}
Dialdehyde starches (DAS) have been used as biomaterials due to their biocompatibility and biodegradability; nonetheless, sweet potato (Ipomea batatas L.) starch has not been researched. Films based on sweet potato DAS, mixed with native starch (NS), poly-vinyl alcohol (PVA) and glycerin have been developed with protein encapsulation, using central composite design (CCD) and response surface methodology (RSM). Input variables were oxidation degree, NS concentration and polymeric mixture volume, while output variables were film's thickness, equilibrium swelling and BSA (Bovine serum albumin) release. DAS was obtained through hydrogen peroxide $\left(\mathrm{H}_{2} \mathrm{O}_{2}\right)$ oxidation, and the oxidation degree is referred to as $\mathrm{H}_{2} \mathrm{O}_{2}$ concentration. Films presented rough surfaces, and formulations containing $10 \% \mathrm{H}_{2} \mathrm{O}_{2}$ DAS presented micropores. Water uptake was greater with higher DAS content. Film thickness depended on the volume of the polymeric suspension and influenced swelling capacity. According to RSM, the optimal formulation was DAS with $5 \% \mathrm{H}_{2} \mathrm{O}_{2}$ and $35 \%$ NS. These results demonstrate that oxidized sweet potato starch has potential for protein encapsulation and delivery.
\end{abstract}

KEYwORDS: Scaffolds, Oxidation, Starch, Biomaterial, Biomedical Applications 


\section{RESUMEN}

Almidones dialdehído (DAS) se han utilizado como biomateriales por su biocompatibilidad y biodegradabilidad; sin embargo, el almidón de camote (Ipomea batatas L.) no ha sido investigado. Se han desarrollado películas de DAS de camote, con almidón nativo (NS), alcohol polivinílico (PVA) y glicerina con encapsulación de proteínas, utilizando un diseño central compuesto (CCD) y metodología de superficie de respuesta (RSM). Las variables de entrada fueron: grado de oxidación, concentración de NS y volumen de la mezcla polimérica, mientras que las variables de salida fueron: espesor de la película, hinchamiento y liberación de BSA (Albúmina de Suero Bovino) en equilibrio. DAS se obtuvo mediante oxidación con peróxido de hidrógeno $\left(\mathrm{H}_{2} \mathrm{O}_{2}\right)$, y el grado de oxidación se define como concentración de $\mathrm{H}_{2} \mathrm{O}_{2}$. Las películas presentaron superficies rugosas y las formulaciones con $10 \% \mathrm{H}_{2} \mathrm{O}_{2}$ DAS presentaron microporos. La absorción de agua fue mayor con mayor contenido de DAS. El espesor de la película dependió del volumen de la mezcla polimérica e influyó en la capacidad de hinchamiento. Según RSM, la formulación óptima fue DAS con $5 \% \mathrm{H}_{2} \mathrm{O}_{2}$ y $35 \%$ NS. Estos resultados demuestran que el almidón de camote oxidado tiene potencial para aplicaciones en la encapsulación y liberación de proteínas.

KEYwORDS: Andamios, Oxidación, Almidón, Biomaterial, Aplicaciones Biomédicas

\section{Corresponding author}

TO: Jose Francisco Alvarez-Barreto

INSTITUTION: Universidad San Francisco de Quito

ADDRESS: Diego de Robles y Vía Interoceánica S/N,

Edif. Hayek, Ofic. H320, P. O. BOX 170901, Quito,

Pichincha, Ecuador

E-MAIL: jalvarezb@usfq.edu.ec

\section{Received:}

12 February 2021

Accepted:

26 April 2021 


\section{INTRODUCTION}

In recent years, macromolecular drugs have been the focus of many therapeutic technologies. Examples include insulin, antibodies, enzymes and other proteins. Extensive research has been carried out also on drug delivery systems for these agents, and the transdermal route has been considered as a possible way to mitigate limitations, such as first passage metabolism, posed by other delivery ways ${ }^{[1]}$.

Protein delivery is also important in tissue engineering. Particularly, the encapsulation and release of growth and differentiation factors can enhance the regeneration process. Chronic skin wounds, genetic skin disorders, burns and diseases, such as diabetes mellitus, may result in important skin damage [2]. Epidermal and fibroblast growth factors are some of the proteins that potentiate skin regeneration [3] [4]. Moreover, traditional medicine has also been used to create optimal conditions for skin growth using natural extracts that have been combined with biopolymers for their effective use ${ }^{[2] ~[5] ~[6] ~[7] . ~}$

Biopolymeric materials traditionally used in these applications include polylactic-acid (PLA), polycaprolactone (PCL), polyacrylonitrile (PAN). However, naturally derived polysaccharides, such as chitosan, alginate, carboxymethyl cellulose, pectin and starch present different advantages like wide availability, certain degree of biomimicry, and many are inherently biocompatible ${ }^{[8]}{ }^{[9]}$. These materials have been used to generate different delivery structures, most commonly hydrogels, films and patches, and have demonstrated great potential for the encapsulation of macromolecular agents [10] [11] [12]. These structures meet the requirements for wound dressings, and transdermal delivery systems, including absorbing exudates and keeping a moist environment that enhances the growth of new granulation tissue, so as to make the wound healing process efficient [2] [3]]. Examples of biomaterial formulations in this area include gelatin-starch hydrogels ${ }^{[14]}$, carboxymethyl cellulose-PEG hydrogels ${ }^{[15]}$, nanofibrous scaffolds ${ }^{[6]}$, polyvinyl alcohol (PVA)-carboxymethyl cellulose and tamarind gum based films ${ }^{[16]}$.

One of the most abundant natural polymers is starch, and it has been extensively studied due to its compatibility, availability, low cost, and biodegradability. Starch can decompose without producing toxic residues, and it is like the native cellular milieu. Thus, starches have been used in the pharmaceutical industry, where they have applications in the manufacturing of soft capsules without gelatin, as bone wax, porous scaffolds and as bio-absorbable materials, such as hydrogels to cure wounds ${ }^{[17][18]}$.

One of the most common problems with starch, however, is its instability in water, and there are two ways to address this issue. One is the use of cross-linking methods with plasticizers like vinyl monomers, glyc-

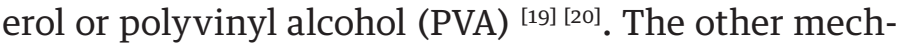
anism is chemical modification, with oxidation being one of the most widely applied in the biomaterials field. Dialdehyde starch (DAS), resulting from oxidation has improved mechanical properties, greater stability in water, and carbonyl groups that can interact with other macromolecules, and thereby, regulate their delivery [21] [2] [23]. DAS has been used as a component in systems for encapsulation and delivery of insulin, different proteins and non-steroidal anti-inflammatory drugs [24] [25]. Nonetheless, the combination of both approaches is also feasible, and hydrogels composed of DAS and PVA have shown potential for the controlled delivery of ibuprofen.

Most drug delivery studies involving DAS have used corn, cassava, or potato as original starch sources, but very little has been done with Ipomea batatas $\mathrm{L}$, a purple tuber from the Convulaceae family. After potato, sweet potato is the second most cultivated tuber in the world, and it is a great source of starches ${ }^{[26]}$. Therefore, 
the aim of this research was to elaborate a film composed of oxidized Ipomea batatas $L$. starch, for protein encapsulation and delivery. Sweet potato DAS was obtained through hydrogen peroxide oxidation, and it was later mixed with PVA and glycerol. A surface response methodology was used to optimize certain film parameters, such as polymer concentration, thickness, and native starch to DAS ratio.

\section{MATERIALS AND METHODS}

\section{Starch Extraction}

Ipomea batatas L., or sweet potato, was used to extract the starch. Briefly, tubers without the skin were cut into $2-\mathrm{cm}$ pieces, and homogenized in a blender, using distilled water at 250 grams per $100 \mathrm{~mL}$. The homogenate was filtered, and the starch could precipitate. Starch was thoroughly washed, discarding the supernatant, and following the same precipitation procedure. After the third wash, rinsing with $70 \% \mathrm{v} / \mathrm{v}$ ethanol was carried out, and the purified starch was dried at $40^{\circ} \mathrm{C}$.

\section{Starch modification}

Starch modification was performed through hydrogen peroxide $\left(\mathrm{H}_{2} \mathrm{O}_{2}\right)$ oxidation, based on the methodology proposed by Zhang ${ }^{[23]}$. Three aqueous hydrogen peroxide solutions, at 3, 5 and $10 \% \mathrm{v} / \mathrm{v}$, were prepared. At the same time, starch was washed with ethanol $70 \% \mathrm{v} / \mathrm{v}$ and twice with distilled water.

A $2 \% \mathrm{w} / \mathrm{v}$ starch suspension was heated until gelatinization at $80^{\circ} \mathrm{C}$ for $30 \mathrm{~min}$, under mild agitation. Then, it was cooled to $25^{\circ} \mathrm{C}$. The oxidation process was carried out under moderate agitation, at a constant $\mathrm{pH}$ value of 7. For every $100 \mathrm{~mL}$ of the starch suspension, $6.25 \mathrm{~mL}$ of the $\mathrm{H}_{2} \mathrm{O}_{2}$ solution, at a given concentration, were added dropwise, in a period of $1 \mathrm{~h}$. The resulting dialdehyde starch (DAS) was centrifuged at $400 \mathrm{~g}$ for 5 min, thoroughly washed with distilled water, and dried at $40^{\circ} \mathrm{C}$.

\section{Starch characterization}

\section{Optical Microscopy}

Starch granules were analyzed in a LEICA DM500 microscope. Granule size was calculated using the LAS EZ microscope software. For every picture, 100 measurements were collected, and an average was reported.

\section{Carbonyl and carboxyl group content}

Modified starch was characterized estimating the amount of carbonyl and carboxyl groups. For carbonyl groups, an adaptation of the protocol proposed by Smith in 1967 was carried out ${ }^{[27]}$, using 1 g of modified starch with $25 \mathrm{~mL}$ of distilled water. The mixture was heated until gelatinization, cooled to $25^{\circ} \mathrm{C}$, and the $\mathrm{pH}$ was corrected to 3.2. After that, $3.75 \mathrm{~mL}$ of hydroxylamine hydrochloride solution (25g of hydroxylamine hydrochloride and $100 \mathrm{~mL}$ of $\mathrm{NaOH}$ $0.5 \mathrm{M}$ in a $500 \mathrm{~mL}$ ) were incorporated, and the mixture was incubated at $40^{\circ} \mathrm{C}$ for $4 \mathrm{~h}$. Then, it was titrated potentiometrically with $0.1 \mathrm{M} \mathrm{HCl}$ until $\mathrm{pH}$ of 3.2. The amount of carbonyl groups was calculated through Equation 1:

$$
\frac{C O}{100 G U}=\frac{\left(\mathrm{V}_{\mathrm{b}}-\mathrm{V}_{\mathrm{s}}\right) \times M \times 0.028 \times 100}{W}
$$

Where $V_{b}$ is the blank titration volume (NS), $V_{s}$ the titration volume of the sample, $M$ is $\mathrm{HCl}$ molarity, and $W$ the dry sample weight.

In a similar procedure, carboxyl group content was determined using the protocol proposed by Parovouri, et. al., in $1995^{[28]}$, using $1 \mathrm{~g}$ of oxidized starch in 60mL of distilled water, gelatinized and titrated to a value of $\mathrm{pH} 8.2$ with $\mathrm{NaOH} 0.01 \mathrm{M}$. Carboxyl groups were determined with Equation 2:

$$
\frac{C O O H}{100 G U}=\frac{\left(\mathrm{V}_{\mathrm{s}}-\mathrm{V}_{\mathrm{b}}\right) \times M \times 0.045 \times 100}{W}
$$


Where $V_{b}$ is the blank titration volume (NS), $V_{s}$ the sample titration volume, $\mathrm{M} \mathrm{HCl}$ molarity and $W$ the weight of the sample dry basis.

\section{Fourier Transformed Infrared Spectroscopy (FT-IR) analysis}

Samples of native starch (NS), oxidized starch at 5\% $\mathrm{H}_{2} \mathrm{O}_{2}$ (DAS5), oxidized starch at $10 \% \mathrm{H}_{2} \mathrm{O}_{2}$ (DAS10) and different film formulations (CCD) were analyzed with a Cary 630 FTIR Spectrometer from Agilent Technologies.

Square samples of $0.5 \mathrm{~cm}$ per side were analyzed with diamond ATR accessory, and spectra were acquired in the region of $4000-500 \mathrm{~cm}^{-1}$.

\section{Design of Experiments (DOE) and Film Preparation}

A statistically designed set of experiments was carried out using response surface methodology (RSM) to minimize the number of experiments and maximize the amount of data generated. Through this analysis, the effect of each parameter/input variable in the film formulation could be evaluated ${ }^{[29]}$.

TABLE 1. Design of experiments to study the effect of the oxidation degree, amount of native starch and volume of polymeric suspension in the composition of each film considering the constant variables to be $2 \% \mathrm{wt} / \mathrm{v}$ PVA, $2 \% \mathrm{v} / \mathrm{v}$ glycerin and $5 \% \mathrm{wt} / \mathrm{wt}$ BSA of the total amount of starch. Design based on the face centered composite design.

\begin{tabular}{l|cccccc}
\hline \multicolumn{6}{c}{ Face centered Central Composite Design } \\
\hline \multirow{2}{*}{ Factor } & \multicolumn{5}{c}{ Levels } \\
\cline { 2 - 6 } & $\mathbf{a}$ & - & $\mathbf{0}$ & + & $\mathbf{A}$ \\
\cline { 2 - 6 } & $\mathbf{- \alpha}$ & $\mathbf{- 1}$ & $\mathbf{0}$ & $\mathbf{1}$ & $\boldsymbol{\alpha}$ \\
\hline Oxidation degree $\left[\% \mathbf{H}_{2} \mathbf{O}_{2}\right] *$ & 0 & 0 & 5 & 10 & 10 \\
\hline NS [wt\%] $* *$ & 0 & 0 & 50 & 100 & 100 \\
\hline Volume [mL] & 12 & 12 & 18.5 & 25 & 25 \\
\hline$*$ Oxidation degree is expressed as the concentration of $\mathrm{H}_{2} \mathrm{O}_{2}(\% \mathrm{v} / \mathrm{v})$ \\
used in the process of modification \\
$* *$ NS: percentage of native starch
\end{tabular}

Using the software JMP, the model was prepared with 34 experiments using a composite design method with a 5-center point model described in Table 1. The input variables were volume of the polymeric suspension, oxidation degree and amount of native starch; the outputs were film thickness, protein release at equilibrium and swelling at equilibrium.

Bovine serum albumin (BSA), Sigma-Aldrich, acted as model protein for encapsulation. Poly (vinylalcohol), PVA, (Mowiol ${ }^{\circledR}$ 18-88, $M_{W} \sim 130,00$, Sigma-Aldrich) was dissolved in distilled water. Each film was made according to Table 1 (DOE). Constant parameters were PVA concentration (2\%wt/v), glycerin concentration $(2 \% \mathrm{v} / \mathrm{v})$ and BSA content (5\%wt of the total starch amount).

First, the amounts of native and oxidized starch were weighed and gelatinized in distilled water and cooled to room temperature. The slurry was transferred to a $50 \mathrm{~mL}$ conical tube, and the PVA, glycerin and BSA solutions were incorporated to the polymeric mixture. Vortex homogenization followed for 30 seconds, and the resulting mixture was placed in polystyrene petri dishes, stored in a freezer at $-14^{\circ} \mathrm{C}$ for $24 \mathrm{~h}$, and subsequently dried at $40^{\circ} \mathrm{C}$ overnight according to preliminary experimentation (data not shown). Once dried, films were stored in the refrigerator at $4^{\circ} \mathrm{C}$.

\section{Film characterization}

\section{Film Thickness}

Film thickness $(\mu \mathrm{m})$ was determined using a micrometer (Mitutoyo, Tokyo, Japan). The film was dried at $37^{\circ} \mathrm{C}$ overnight, and the thickness was determined as the average of measurements in 8 random locations.

\section{Film swelling and protein release}

Films were dried at $37^{\circ} \mathrm{C}$ overnight. They were then weighed, and 4 squares of $0.7 x \cdot 0.7 \mathrm{~cm}$ were cut from each film. These squares were placed in 24 well-plates, 
filled with Phosphate Buffer Saline (PBS at pH 7.2). During the first hour of the experiment the film was weighted every 15 minutes, and a known volume of the supernatant was collected and replaced with fresh PBS. After that, samples were weighed at 5, 24, 48, and $72 \mathrm{~h}$, and supernatant was collected. According to previous analyses, equilibrium was already reached at $72 \mathrm{~h}$ (data not shown).

The swelling ratio was calculated by Equation $3^{[17]}$ :

$$
S W=\frac{M_{t}-M_{0}}{M_{0}} \times 100 \%
$$

Where $S W$ is the swelling percentage, $M_{t}$ is sample weight at equilibrium, and $M_{o}$ is the initial sample.

Protein release was determined by the Bradford method, through the collected supernatant aliquots. A calibration curve was made with BSA solutions of known concentrations in PBS ${ }^{[30]}$.

\section{Scanning Electron Microscopy (SEM)}

Samples were analyzed in a JEOL JSM-IT300 scanning electron microscope, using the program MP-96040EXCS External Control Software. Starch samples were observed at $50 \mathrm{~Pa}$ and $5 \mathrm{kV}$, while films were analyzed at $30 \mathrm{~Pa}$ and $5 \mathrm{kV}$ to avoid sample damage by the electron beam.

\section{RESULTS AND DISCUSSION}

\section{Starch extraction and modification}

\section{Yield, size and morphology}

The process of starch extraction from ipomea batatas $L$. presented a yield of $14.44 \%$, with respect to the total mass of the tuber processed. Starch granule had an average size of $(23.18 \pm 7.25) \mu m$. Sweet potato starch presented a spherical bell form, as seen in previous studies where this unusual shape is described [31] [32].

\section{Carbonyl and carboxyl group content}

Chemical modification is generally practiced in food and non-food industry as it gives functional groups to the starch, changing its properties and thereby, its functionality ${ }^{[22]}$. Functional groups resulting from hydroxyl group oxidation are carbonyl and carboxyl; their quantification values in this work are shown in Table 2. Carbonyl and carboxyl group content depends on the $\mathrm{pH}$ value, temperature, and reaction time, among others; therefore, it is described as a complex reaction by Salmi, et al. ${ }^{[33]}$. In the present study, the oxidation with $\mathrm{H}_{2} \mathrm{O}_{2}$ at 5 and $10 \% \mathrm{v} / \mathrm{v}$ yields carbonyl and carboxyl groups comparable to the study made by Zhang, et al., where the highest carbonyl and aldehyde groups where reached in the oxidation with molar ratio of $\mathrm{H}_{2} \mathrm{O}_{2} /$ starch $<0.7$ which is equivalent to a $10 \%$ $\mathrm{H}_{2} \mathrm{O}_{2}$ percentage ${ }^{[23]}$.

The amount of carboxyl groups is smaller than carbonyl groups (Table 2), which is appropriate since the purpose of the oxidation is to obtain carbonyl groups as they are responsible for providing greater stability in water, and they can form Schiff bases with the amine groups from proteins.

TABLE 2. Carbonyl and carboxyl group content in the dialdehyde sweet potato starch.

\begin{tabular}{cccc}
\hline $\begin{array}{c}\mathrm{H}_{2} \mathrm{O}_{2} \text { Percent } \\
{[\% \mathrm{v} / \mathrm{v}]}\end{array}$ & $\begin{array}{c}\text { Carbonyl } \\
{[\mathrm{CO} / 100 \mathrm{GU}]}\end{array}$ & $\begin{array}{c}\text { Carboxyl } \\
{[\mathrm{COOH} / 100 \mathrm{GU}]}\end{array}$ & $\begin{array}{c}\text { Total oxidation } \\
{[\mathrm{CO}+\mathrm{COOH} / 100 \mathrm{GU}]}\end{array}$ \\
\hline $\mathbf{3}$ & $0.157 \pm 0.040$ & $0.023 \pm 0.001$ & $0.220 \pm 0.327$ \\
\hline $\mathbf{5}$ & $0.432 \pm 0.010$ & $0.066 \pm 0.003$ & $0.508 \pm 0.013$ \\
\hline $\mathbf{1 0}$ & $0.534 \pm 0.022$ & $0.070 \pm 0.002$ & $0.627 \pm 0.021$ \\
\hline
\end{tabular}

\section{Design of Experiments (DOE)}

Experimental factors were analyzed according to the important responses for the development of films for potential protein encapsulation and delivery. In this work, films were developed using a methodology previously established in the laboratory. The response variables were protein release, swelling at equilibrium, 
and thickness of the films. These responses are important as it is not expected that all the protein is released completely. It is possible that amine groups in the protein form Schiff's bases with DAS carbonyl groups. Swelling is an important response as the wound needs humidity to heal and it would exudate fluids in the process; thus, the film needs to absorb a great amount of those exudates ${ }^{[34]}$. Additionally, swelling capacity is directly related to protein delivery ${ }^{[35]}$.

\begin{tabular}{|c|c|c|c|}
\hline \multicolumn{4}{|c|}{$\nabla$ Variable Importance: Independent Uniform Inputs } \\
\hline \multicolumn{4}{|c|}{$\Delta$ Summary Report } \\
\hline \multicolumn{4}{|l|}{$\triangle$ Overall } \\
\hline Column & Main Effect & Total Effect & $\begin{array}{cccc}.2 & .4 & .6 & .8 \\
\end{array}$ \\
\hline Volume $[\mathrm{mL}]$ & 0.523 & 0.567 & 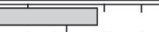 \\
\hline Oxidation percentage $\left[\% \mathrm{H}_{2} \mathrm{O} 2\right]$ & 0.246 & 0.338 & $\square, \quad \mid$ \\
\hline NS [wt\%] & 0.124 & 0.197 & 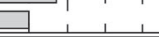 \\
\hline \multicolumn{4}{|c|}{$\triangle$ Equilibrium Swelling [\%] } \\
\hline Column & Main Effect & Total Effect & $\begin{array}{lll}4 & .6 & .8 \\
\end{array}$ \\
\hline Oxidation percentage [\% $\mathrm{H} 2 \mathrm{O} 2]$ & 0.410 & 0.444 & 71 \\
\hline Volume $[\mathrm{mL}]$ & 0.293 & 0.311 & $\square 1$ \\
\hline NS [wt\%] & 0.245 & 0.285 & $\square$, \\
\hline \multicolumn{4}{|l|}{$\Delta$ Equilibrium Release [\%] } \\
\hline \begin{tabular}{|l|} 
Column \\
\end{tabular} & Main Effect & Total Effect & .2 .4 .6 \\
\hline Oxidation percentage [\% $\% 2 \mathrm{O} 2]$ & 0.312 & 0.537 & $\square^{1}$ \\
\hline Volume $[\mathrm{mL}]$ & 0.376 & 0.465 & $\square$ । \\
\hline NS [wt\%] & 0.087 & 0.227 & $\square$ \\
\hline \multicolumn{4}{|l|}{$\Delta$ Thickness [mm] } \\
\hline Column & Main Effect & Total Effect & $\begin{array}{llll}.2 & .4 & .6 & .8 \\
\end{array}$ \\
\hline Volume $[\mathrm{mL}]$ & 0.901 & 0.926 & \\
\hline NS [wt\%] & 0.039 & 0.078 & 11 \\
\hline Oxidation percentage $\left[\% \mathrm{H}_{2} \mathrm{O} 2\right]$ & 0.015 & 0.034 & \\
\hline
\end{tabular}

\section{FIGURE 1. Importance of each input variable depending} on the output obtained in the experimentation process.

Great deviations in central points can be seen for protein release response, giving a great experimental error as data from the central point variates greatly from one another; nevertheless, for thickness and swelling, variations were low in central points, with small experimental errors. According to Figure 1, in the overall analysis, the volume of the polymeric suspension had a greater effect, followed by the degree of oxidation, and lastly, the amount of native starch in the formulation. The parameters with greater effects on each response are also described; for swelling and protein release in equilibrium it was the oxidation degree; in the release, the effect of the degree of oxidation and volume of polymeric suspension are close, so both are important in the response. Finally, and as expected, the thickness of the film depends on the volume of the polymeric suspension almost in its entirety.

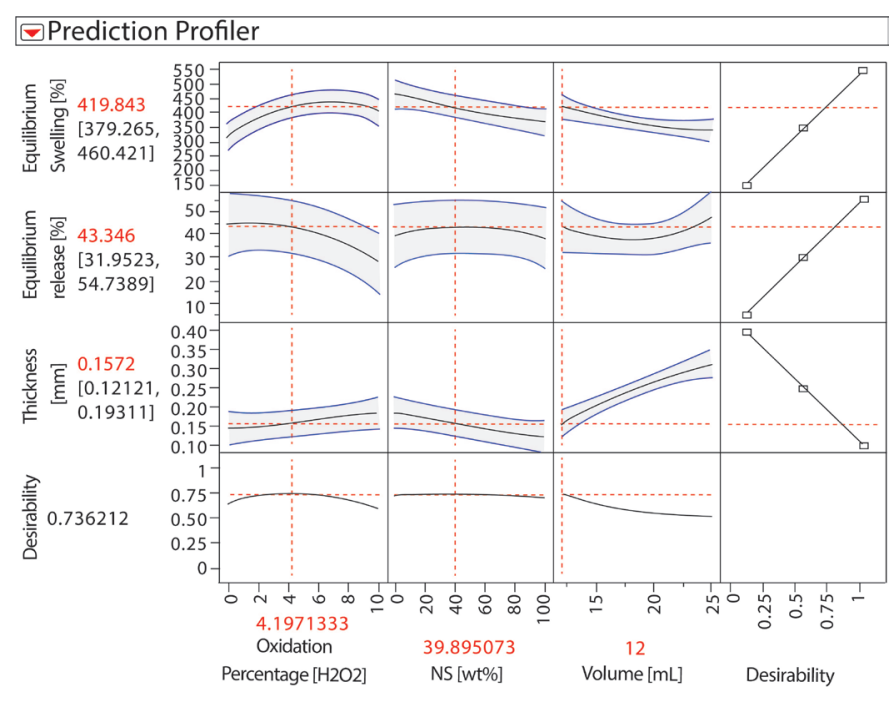

FIGURE 2. DOE prediction profiles for output

variables: thickness, equilibrium swelling and equilibrium release, dependent on oxidation degree,

NS content and polymeric mixture volume.

In Figure 2, influences of each parameter in the responses are described. For equilibrium swelling, the degree of oxidation shows a maximum around $7 \%$. NS content also influences the release, and it presents a maximum when no NS is added to the formulation. For protein release at equilibrium, as the degree of oxidation and volume of polymeric suspension are important parameters, this figure shows the model with each predicted response. Release decreased at greater degree of oxidation, which is consistent with the hypothesis that proteins could be immobilized through Schiff bases with the carbonyl groups of the oxidized starch. The prediction of the model shows, in red lines, the values of the input variables needed to maximize swelling and protein release at equilibrium, while minimizing the film thickness. The model has predicted that the amount of NS should be approximately 35\%, oxidation degree approximately $4 \%$ and volume $12 \mathrm{~mL}$. The available DAS, how- 
a)

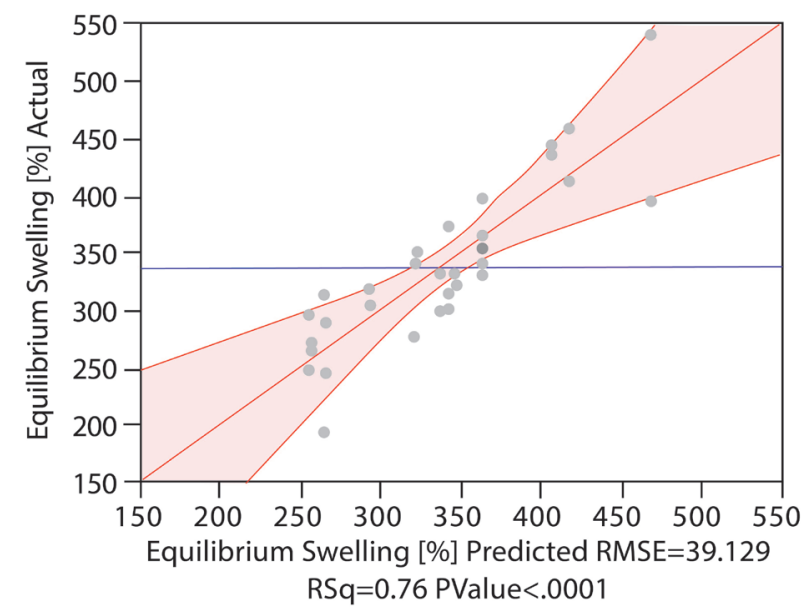

b)

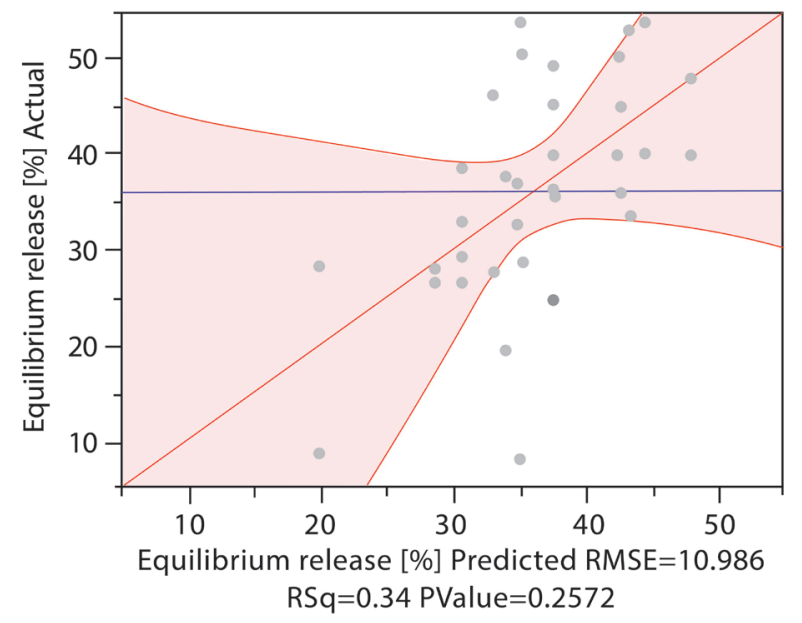

c)

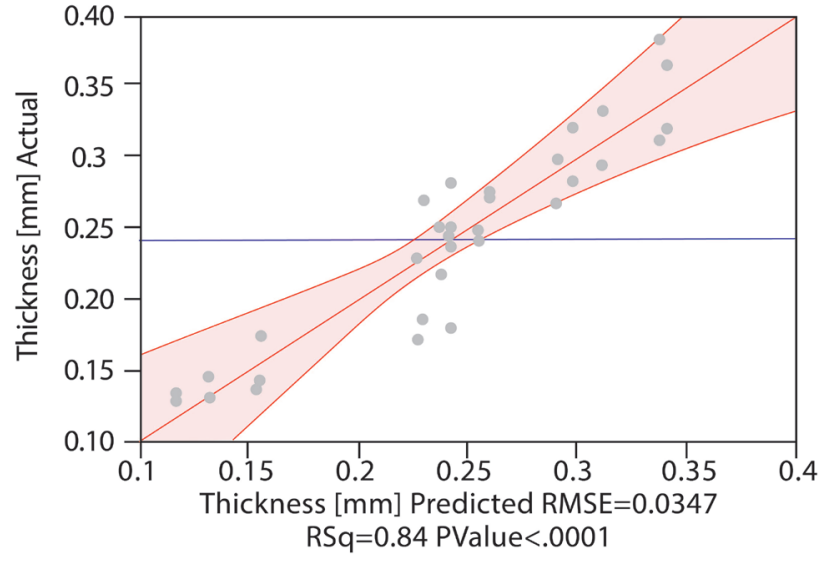

FIGURE 3. Variability of the responses according to the variables. Actual (grey dots) and predicted data for the model. a) Equilibrium Swelling,

b) Equilibrium release, c) Thickness.

ever, were oxidized at 5 and $10 \% \mathrm{H}_{2} \mathrm{O}_{2}$, so it was decided to use $5 \%$ degree of oxidation for model testing, since it was closest to the optimal value.
Differences between the predicted model and experimental data are showed in Figure 3. It can be seen that the experimental data fits the swelling predicted model as it has a $\mathrm{P}<0.0001$, and the confidence level was established at $95 \%(\mathrm{P}<0.05)$. For the thickness model, experimental data also fits with a $\mathrm{P}<0.0001$; however, the model does not fit the experimental data for the protein release, with $\mathrm{P}=0.22$.

According to the literature, the levels of oxidation reached in this work were low, as no catalyst was used. Thus, some hydroxyl groups were still present and those are responsible for water absorption; when starches have a high degree of oxidation, most of these groups are used so it decreases the swelling ${ }^{[22]}$. These results are comparable to those reported by Nourmohammadi, et al., where they developed bioactive composite scaffolds with polycaprolactone, chitosan and oxidized starch; as more DAS was included in the formulations, swelling rates increased because of greater starch hydroxyl group content ${ }^{[36]}$.

To corroborate the generated prediction model, two more experiments were carried out: one with a formulation close to the optimum predicted by the program, using DAS5 and $35 \%$ of NS in a $12 \mathrm{~mL}$ volume of polymeric mix, and one with no NS with the same conditions. In Table 3, the results of this set of experiments are shown.

TABLE 3. Results from de corroboration of the DOE.

\begin{tabular}{cc|ccc}
\hline \multicolumn{2}{c|}{ Film's Composition } & \multicolumn{3}{|c}{ Model deviation [\%] } \\
\hline $\begin{array}{c}\text { NS } \\
{[\%]}\end{array}$ & $\begin{array}{c}\text { DAS5 } \\
{[\%]}\end{array}$ & $\begin{array}{c}\text { Thickness } \\
{[\mathrm{mm}]}\end{array}$ & $\begin{array}{c}\text { Swelling } \\
{[\%]}\end{array}$ & $\begin{array}{c}\text { Release } \\
{[\%]}\end{array}$ \\
\hline 35 & 65 & 10.151 & 7.8766 & 37.152 \\
\hline 0 & 100 & 16.949 & 9.7800 & 55.072 \\
\hline
\end{tabular}

Thickness and swelling in equilibrium are parameters that were adjusted to the model prediction, as they displayed a deviation from the model of less than $17 \%$, and the equilibrium release does not fit the 
model as its deviation for the model is about $37 \%$ using DAS5 and 35\% of NS, which is comparable with the other results where equilibrium release showed a big variability. These differences were expected, as equilibrium release presented the largest dispersion of the data, and the model did not fit the experimental results (as seen in Figure 3).

\section{Fourier Transform Infrared Spectroscopy (FT-IR) of the films}

Figure 4 shows the spectra for a film containing PVA, glycerin and BSA, compared to a film containing NS, PVA, glycerin and BSA. Around $1539 \mathrm{~cm}^{-1}$, it can be observed that there is a difference in the wavenumber which corresponds to $\mathrm{N}-\mathrm{H}$ bending and $\mathrm{C}-\mathrm{H}$ stretching vibration of amine II present in the planar peptidic bond vibrational modes of BSA molecules [35] [37].

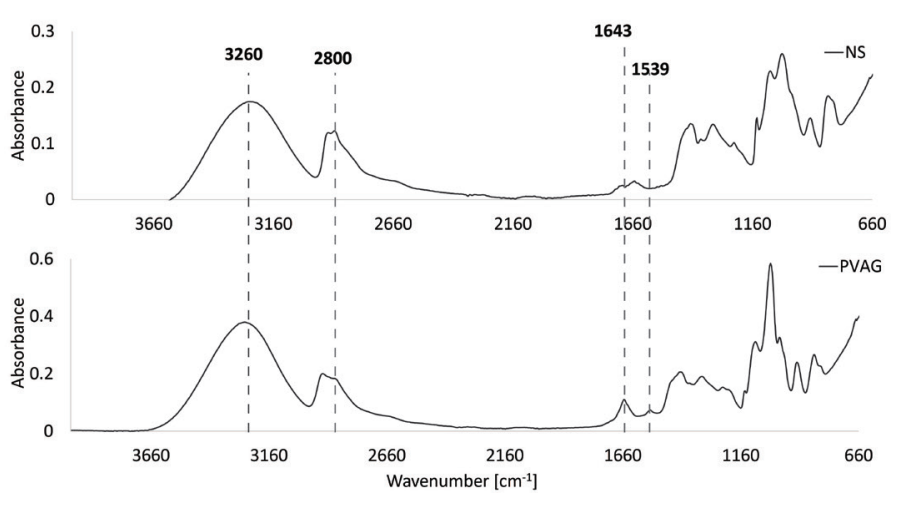

FIGURE 4. FT-IR spectra of film formulations:

a) with native starch, and b) without starch (only PVA and glycerin).

The same pattern is observed in Figure 5 for DAS5 and similar patterns in DAS10, as the peak intensity decreases when using more NS. At $1643 \mathrm{~cm}^{-1}$ a peak corresponding to $\mathrm{C}-\mathrm{N}$ bonds that are assumed to correspond to Schiff bases $(\mathrm{C}=\mathrm{O}$ bending vibrations and $\mathrm{C}-\mathrm{N}$ stretching) is seen ${ }^{[38]}$. This wavenumber shows a bigger peak when no NS is used, thereby corroborating that it corresponds to Schiff bases formed between the protein and DAS. In Figure 5, when NS is used at 50\%, the interactions $\mathrm{C}-\mathrm{N}$ decrease; this could be as less car- bonyl groups are present Schiff base cannot form with amines from the BSA. Nevertheless, when using the optimal composition with NS 35\% these interactions are similar as using no starch (PVAG). This could be due to the availability of carbonyl groups.

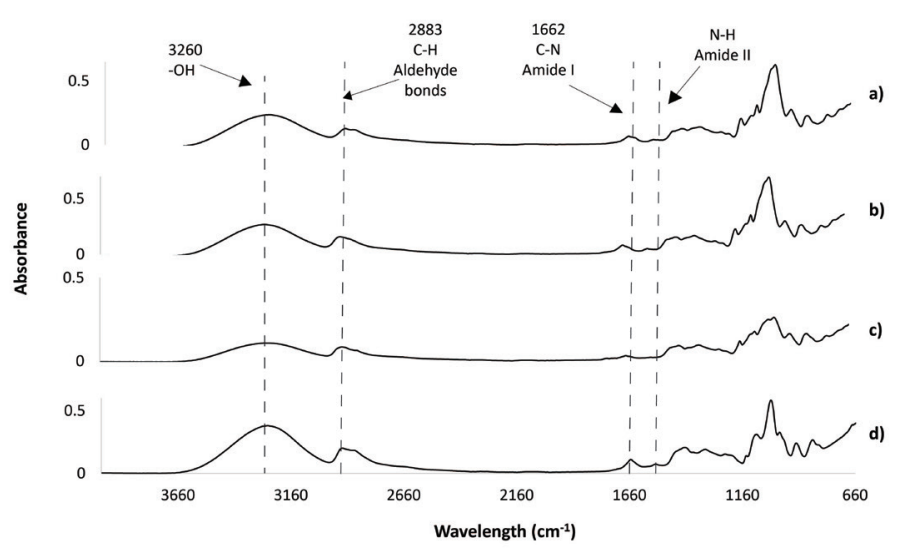

FIGURE 5. FT-IR spectra of films formulations with:

a) DAS5 + 2\% wt/v PVA + 2\%v/v Glycerin + BSA,

b) DAS5 with $50 \%$ NS + 2\% wt/v PVA + 2\%v/v Glycerin +

BSA (DAS5NS50), and c) the optimal composition with

DAS5 with 35\% NS + 2\% wt/v PVA + 2\%v/v Glycerin +

BSA (DAS5NS35), compared with d) without starch

(only PVA and glycerin. PVAG).

Peaks around $3260 \mathrm{~cm}^{-1}$ correspond to hydroxyl groups $(-\mathrm{OH})$, those are from PVA, glycerin and the starches. Hydroxyl groups are responsible for the water absorption in the films ${ }^{[22]}$. Here, there could be a confirmation for the model as less quantity of NS is present more hydroxyl groups are present in the films, so they can uptake more water and the swelling rates increases.

Finally, peaks around $1000 \mathrm{~cm}^{-1}$ are characteristic for NS, glycerin and PVA, in the three figures below the same pattern is present, when NS is present the peaks are smaller, this could be that the NS is not interacting with PVA or glycerin. Some of the characteristic peaks from glycerin and PVA shift when in the presence of starch, probably indicating important interactions between the plasticizers and the polysaccharide. 


\section{Film Morphology}

Film surfaces were assessed through SEM for morphological analyses. A sample for five different formulations were analyzed. Surfaces of the films are uniform, with important rugosity, as seen in Figure 6.
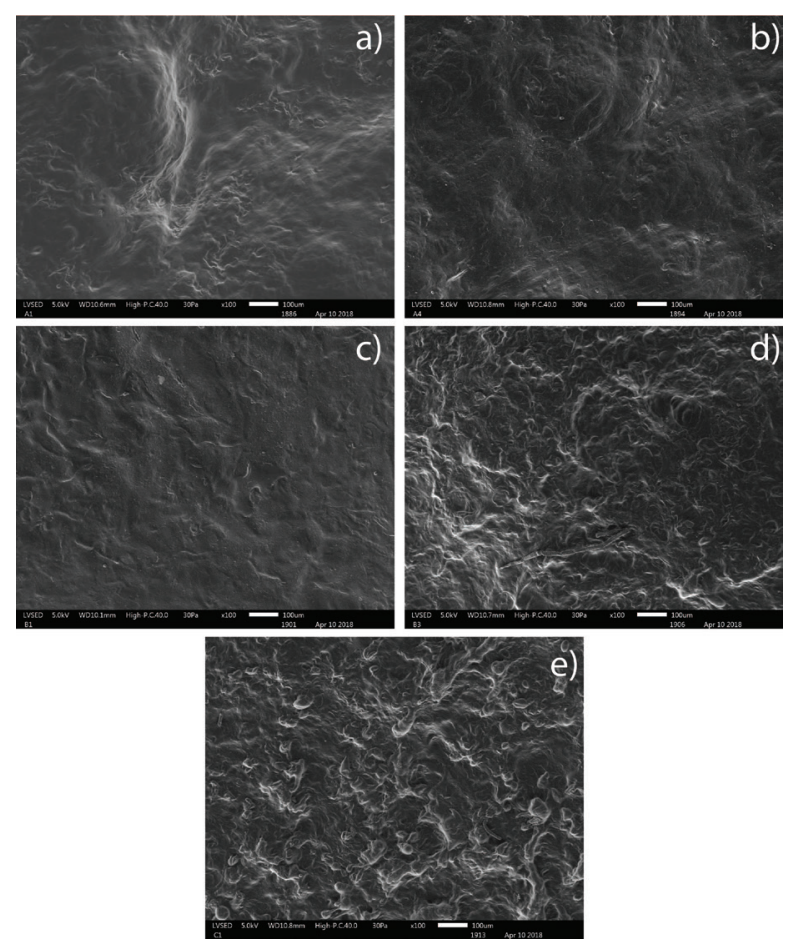

FIGURE 6. Scanning Electron Microscopy for samples with different compositions at 100X. a) DAS10 + 2\% wt/v PVA + 2\%v/v Glycerin + BSA; b) DAS10 with $50 \%$ NS + 2\% wt/v PVA + 2\%v/v Glycerin + BSA; c) DAS5 + $2 \% \mathrm{wt} / \mathrm{v}$ PVA + 2\%v/v Glycerin + BSA; d) DAS5 with $50 \%$

NS + 2\% wt/v PVA + 2\%v/v Glycerin + BSA; e) $100 \%$ NS + 2\% wt/v PVA + 2\%v/v Glycerin + BSA.

Samples with DAS10 present micropores which can be seen in Figure 6, a), and micropores are also present for samples with DAS10 and 50\% NS in Figure 6, b). These can influence water absorption, and help oxygen exchange, corroborating the results from swelling at equilibrium ${ }^{[39]}$. Formulations with DAS10, DAS10 50\% NS and DAS5 (a, b, c), respectively, present smoother surfaces, according to previous studies for films with gelatin and oxidized starch gelatin, film smoothness represent the crosslinking ability of oxi- dized starch and a great integration between all the components of the films ${ }^{[40]}$. Formulations with DAS5 50\%NS and 100\% NS in Figure 6, d), and Figure 6, e), respectively, present more rugosity than the films described previously. This could be due to insufficient homogenization between all components and caused by the high viscosity of gelatinized NS. For tissue engineering, pores are important as they allow permeability of oxygen and essential nutrients ${ }^{[35]}$, also they allow more water uptake which is beneficial in early healing stages since cells will depend completely on nearby tissue fluids ${ }^{[4]}{ }^{[42]}$. Another important fact with this type of scaffolds is that the roughness is necessary for cell adhesion. Some studies revealed that for osteoblasts rough surfaces shows great cell adhesion and proliferation [43] [44]; for fibroblasts studies demonstrate that this type of cells prefer rough surfaces instead of smooth ones, as the studies showed more cells in rough surfaces than in smoother ones ${ }^{[35]}$.

\section{CONCLUSIONS}

The response surface methodology (RSM) for this work gives a model that fits for thickness and swelling parameters; however, protein release was poorly predicted. According to the DOE, the parameter with the greatest effect on the overall system was the volume followed by the degree of oxidation and percentage of NS. Swelling and protein release are responses that mostly depend on the degree of oxidation and are correlated; as swelling rates increases the release increases, this is also a good fact as these films need to absorb exudates from the wound and promote its healing. FT-IR spectra for the films show that some Schiff bases may be formed when less NS is used, and the peaks for hydroxyl groups may confirm the swelling rates for the films, when they have less NS they absorb more water which is beneficial for wound healing. Nevertheless, the films compositions performed showed properties that may be useful for protein encapsulation and release for different applications, such as transdermal delivery or skin regeneration 
Studies on cytocompatibility, cytotoxicity, cell adhesion, biocompatibility, biodegradability, and in vivo studies must be performed.

\section{AUTHOR CONTRIBUTIONS}

J.A.B. designed the experimental planning, carried out data analyses and FTIR; participated in the manuscript preparation. D.V.N. did the film preparation and characterization, carried out data analyses and participated in the manuscript preparation. J.S.P.A. generated SRM and carried out the subsequent analysis. A.C. contributed with the protein entrapment and release characterization. M.G. did the material charac- terization and participated in writing the manuscript. L.E. participated in the protein entrapment and in vitro release and participated in the manuscript preparation. M. V. did the scanning electron microscopy.

\section{ACKNOWLEDGEMENT}

Funding for this work was provided by the POLIGRANT and MedGrant Funds, as well as Collaboration Grant Program from USFQ.

\section{COMPETING INTERESTS STATEMENT}

The authors declare no competing interests regarding the present study. 


\section{REFERENCES}

[1] Chaulagain B, Jain A, Tiwari A, Verma A, et al. Passive delivery of protein drugs through transdermal route. Artif Cells Nanomed Biotechnol [Internet]. 2018;46(sup1):472-87. Available from: https://doi.org/10.1080/21691401.2018.1430695

[2] López Angulo DE, do Amaral Sobral PJ. Characterization of gelatin/ chitosan scaffold blended with aloe vera and snail mucus for biomedical purpose. Int J Biol Macromol [Internet]. 2016;92:645-53. Available from: https://doi.org/10.1016/j.ijbiomac.2016.07.029

[3] Sharma P, Kumar P, Sharma R, Bhatt VD, et al. Tissue Engineering; Current Status \& Futuristic Scope. J Med Life [Internet]. 2019;12(3):225-9. Available from: https://doi.org/10.25122/iml-2019-0032

[4] Augustine R, Hasan A, Dalvi YB, Rehman U, et al. Growth factor loaded in situ photocrosslinkable poly(3-hydroxybutyrate-co-3hydroxyvalerate)/gelatin methacryloyl hybrid patch for diabetic wound healing. Mater Sci Eng C [Internet]. 2021;118:111519. Available from: https://doi.org/10.1016/j.msec.2020.111519

[5] Wu D, Bäckström E, Hakkarainen M. Starch Derived Nanosized Graphene Oxide Functionalized Bioactive Porous Starch Scaffolds. Macromol Biosci [Internet]. 2017;17(6):1600397. Available from: https://doi.org/10.1002/mabi.201600397

[6] Unnithan AR, Pichiah T, Gnanasekaran G, Seenivasan K, et al. Emu oil-based electrospun nanofibrous scaffolds for wound skin tissue engineering. Colloid Surf A-Physicochem Eng Asp [Internet]. 2012;415:454-60. Available from: https://doi.org/10.1016/j.colsurfa.2012.09.029

[7] Panawes S, Ekabutr P, Niamlang P, Pavasant P, et al. Antimicrobial mangosteen extract infused alginate-coated gauze wound dressing. J Drug Deliv Sci Technol [Internet]. 2017;41:182-90. Available from: https://doi.org/10.1016/j.jddst.2017.06.021

[8] Croisier F, Jérôme C. Chitosan-based biomaterials for tissue engineering. Eur Polym J [Internet]. 2013;49(4):780-92. Available from: https://doi.org/10.1016/j.eurpolymj.2012.12.009

[9] Wang J, Sun B, Tian L, He X, et al. Evaluation of the potential of rhTGF- $\beta 3$ encapsulated P(LLA-CL)/collagen nanofibers for tracheal cartilage regeneration using mesenchymal stems cells derived from Wharton's jelly of human umbilical cord. Mater Sci Eng C [Internet]. 2017;70(1):637-45. Available from: https://doi.org/10.1016/j.msec.2016.09.044

[10] Devi N, Sarmah M, Khatun B, Maji TK. Encapsulation of active ingredients in polysaccharide-protein complex coacervates. Adv Colloid Interface Sci [Internet]. 2017;239:136-45. Available from: https://doi.org/10.1016/j.cis.2016.05.009

[11] Shariatinia Z. Pharmaceutical applications of chitosan. Adv Colloid Interface Sci [Internet]. 2019;263:131-94. Available from: https://doi.org/10.1016/j.cis.2018.11.008

[12] Dhamecha D, Movsas R, Sano U, Menon JU. Applications of alginate microspheres in therapeutics delivery and cell culture: Past, present and future. Int J Pharm [Internet]. 2019;569:118627. Available from: https://doi.org/10.1016/j.ijpharm.2019.118627

[13] Ramanathan G, Singaravelu S, Muthukumar T, Thyagarajan S, et al. Design and characterization of 3D hybrid collagen matrixes as a dermal substitute in skin tissue engineering. Mater Sci Eng C [Internet]. 2017;72:359-70. Available from: https://doi.org/10.1016/j.msec.2016.11.095
[14] Van Nieuwenhove I, Salamon A, Peters K, Graulus G-J, et al. Gelatinand starch-based hydrogels. Part A: Hydrogel development, characterization and coating. Carbohydr Polym [Internet]. 2016;152:129-39. Available from: https://doi.org/10.1016/j.carbpol.2016.06.098

[15] Capanema NSV, Mansur AAP, de Jesus AC, Carvalho SM, et al. Superabsorbent crosslinked carboxymethyl cellulose-PEG hydrogels for potential wound dressing applications. Int J Biol Macromol [Internet]. 2018;106:1218-34. Available from: https://doi.org/10.1016/j.ijbiomac.2017.08.124

[16] Yadav I, Rathnam VSS, Yogalakshmi Y, Chakraborty S, et al. Synthesis and characterization of polyvinyl alcohol- carboxymethyl tamarind gum based composite films. Carbohydr Polym [Internet]. 2017;165:159-68. Available from: https://doi.org/10.1016/j.carbpol.2017.02.026

[17] Li Y, Tan Y, Xu K, Lu C, et al. A biodegradable starch hydrogel synthesized via thiol-ene click chemistry. Polym Degrad Stab [Internet]. 2017;137:75-82. Available from: https://doi.org/10.1016/i.polymdegradstab.2016.07.015

[18] Nasri-Nasrabadi B, Mehrasa M, Rafienia M, Bonakdar S, Behzad T, et al. Porous starch/cellulose nanofibers composite prepared by salt leaching technique for tissue engineering. Carbohydr Polym [Internet]. 2014;108:232-8. Available from: https://doi.org/10.1016/i.carbpol.2014.02.075

[19] Waghmare VS, Wadke PR, Dyawanapelly S, Deshpande A, et al. Starch based nanofibrous scaffolds for wound healing applications. Bioact Mater [Internet]. 2018;3(3):255-266. Available from: https://doi.org/10.1016/j.bioactmat.2017.11.006

[20] Kalia S, Avérous L. Biodegradable and Biobased Polymers for Environmental and Biomedical Applications. Beverly, MA: Wiley; 2016. 501p.

[21] Zuo Y, Liu W, Xiao J, Zhao X, et al. Preparation and characterization of dialdehyde starch by one-step acid hydrolysis and oxidation. Int J Biol Macromol [Internet]. 2017;103:1257-64. Available from: https://doi.org/10.1016/j.ijbiomac.2017.05.188

[22] Zhang Y-R, Wang X-L, Zhao G-M, Wang Y-Z. Preparation and properties of oxidized starch with high degree of oxidation. Carbohydr Polym [Internet]. 2012;87:2554-62. Available from: https://doi.org/10.1016/j.carbpol.2011.11.036

[23] Zhang S-D, Zhang Y-R, Wang X-L, Wang Y-Z. High Carbonyl Content Oxidized Starch Prepared by Hydrogen Peroxide and Its Thermoplastic Application. Staerke [Internet]. 2009;61:646-55. Available from: https://doi.org/10.1002/star.200900130

[24] Wen N, Lü S, Xu X, Ning P, et al. A polysaccharide-based micellehydrogel synergistic therapy system for diabetes and vascular diabetes complications treatment. Mater Sci Eng C [Internet]. 2019;100:94-103. Available from: https://doi.org/10.1016/j.msec.2019.02.081

[25] Nada AA, Soliman AAF, Aly AA, Abou-Okeil A. Stimuli-Free and Biocompatible Hydrogel via Hydrazone Chemistry: Synthesis, Characterization, and Bioassessment. Staerke [Internet]. 2018;71:1800243. Available from: https://doi.org/10.1002/star.201800243 
[26] El Sheikha AF, Ray RC. Potential impacts of bioprocessing of sweet potato: Review. Crit Rev Food Sci Nutr [Internet]. 2017;57(3):455-71. Available from: https://doi.org/10.1080/10408398.2014.960909

[27] Smith RJ. Characterization and analysis of starches. In: Whistler RL, Paschall EF (eds.). Starch: Chemistry and Technology. New York: Academic Press; 1967:620-625p.

[28] Parovuori P, Hamunen A, Forssell P, Autio K, et al. Oxidation of Potato Starch by Hydrogen Peroxide. Staerke [Internet]. 1995;47(1):19-23. Available from: https://doi.org/10.1002/star.19950470106

[29] Ellens CJ. Design, optimization and evaluation of a free-fall biomass fast pyrolysis reactor and its products. [Master's thesis]. [Iowa]: Iowa State University, 2009: 155.

[30] Nomani A, Nosrati H, Manjili HK, Khesalpour L, et al. Preparation and Characterization of Copolymeric Polymersomes for Protein Delivery. Drug Res [Internet]. 2017;67(8):458-65. Available from: https://doi.org/10.1055/s-0043-106051

[31] Osundahunsi OF, Fagbemi TN, Kesselman E, Shimoni E. Comparison of the Physicochemical Properties and Pasting Characteristics of Flour and Starch from Red and White Sweet Potato Cultivars. J Agric Food Chem [Internet]. 2003;51(8):2232-6. Available from: https://doi.org/10.1021/jf0260139

[32] Pérez S, Baldwin PM, Gallant DJ. Structural Featurs of Starch Granules I. In: BeMiller J, Whistler R (eds). Food Science and Technology [Internet]. Academic Press; 2009. 149-192p. Available from: https://doi.org/10.1016/B978-0-12-746275-2.00005-7.

[33] Salmi T, Tolvanen $P$, Wärnå J, Mäki-Arvela P, et al. Mathematical modeling of starch oxidation by hydrogen peroxide in the presence of an iron catalyst complex. Chem Eng Sci [Internet]. 2016;146:1925. Available from: https://doi.org/10.1016/j.ces.2016.02.027

[34] Lyu Y, Ren H, Yu M, Li X, et al. Using oxidized amylose as carrier of linalool for the development of antibacterial wound dressing. Carbohydr Polym [Internet]. 2017;174:1095-105. Available from: https://doi.org/10.1016/j.carbpol.2017.07.033

[35] Silva R, Singh R, Sarker B, Papageorgiou DG, et al. Hydrogel matrices based on elastin and alginate for tissue engineering applications. Int J Biol Macromol [Internet]. 2018;114:614-25. Available from: https://doi.org/10.1016/j.ijbiomac.2018.03.091

[36] Nourmohammadi J, Ghaee A, Liavali SH. Preparation and characterization of bioactive composite scaffolds from polycaprolactone nanofibers-chitosan-oxidized starch for bone regeneration. Carbohydr Polym [Internet]. 2016;138:172-9. Available from: https://doi.org/10.1016/i.carbpol.2015.11.055
[37] Tang IM, Krishnamra N, Charoenphandhu N, Hoonsawat R, et al. Biomagnetic of Apatite-Coated Cobalt Ferrite: A Core-Shell Particle for Protein Adsorption and pH-Controlled Release. Nanoscale Res Lett [Internet]. 2011;6:19. Available from: https://doi.org/10.1007/s11671-010-9761-4

[38] Li D, Ye Y, Li D, Li X, et al. Biological properties of dialdehyde carboxymethyl cellulose crosslinked gelatin-PEG composite hydrogel fibers for wound dressings. Carbohydr Polym [Internet]. 2016;137:508-14. Available from: https://doi.org/10.1016/j.carbpol.2015.11.024

[39] Arockianathan PM, Sekar S, Kumaran B, Sastry TP. Preparation, characterization and evaluation of biocomposite films containing chitosan and sago starch impregnated with silver nanoparticles. Int J Biol Macromol [Internet]. 2012;50(4):939-46. Available from: https://doi.org/10.1016/j.ijbiomac.2012.02.022

[40] Moreno O, Cárdenas J, Atarés L, Chiralt A. Influence of starch oxidation on the functionality of starch-gelatin based active films. Carbohydr Polym [Internet]. 2017;178:147-58. Available from: https://doi.org/10.1016/j.carbpol.2017.08.128

[41] Liu Y, Ma L, Gao C. Facile fabrication of the glutaraldehyde crosslinked collagen / chitosan porous scaffold for skin tissue engineering. Mater Sci Eng C [Internet]. 2012;32(8):2361-6. Available from: https://doi.org/10.1016/j.msec.2012.07.008

[42] Li T, Song X, Weng C, Wang X, et al. Self-crosslinking and injectable chondroitin sulfate/pullulan hydrogel for cartilage tissue engineering. Appl Mater Today [Internet]. 2018;10:173-83. Available from: https://doi.org/10.1016/j.apmt.2017.12.002

[43] Zareidoost A, Yousefpour M, Ghaseme B, Amanzadeh A. The relationship of surface roughness and cell response of chemical surface modification of titanium. J Mater Sci Mater Med [Internet]. 2012;23:1479-88. Available from: https://doi.org/10.1007/s10856-012-4611-9

[44] Hou Y, Xie W, Yu L, Cuellar Camacho L, et al. Surface Roughness Gradients Reveal Topography-Specific Mechanosensitive Responses in Human Mesenchymal Stem Cells. Small[Inter net].2020;16(10):1905422. Available from: https://doi.org/10.1002/smll.201905422 